\title{
FENUGREEK SEED AND ITS ACTIVE AGENT DIOSGENIN TREATMENT EFFECTS ON DIFFERENT METABOLIC PARAMETERS IN RATS
}

\author{
ANDREA BADALE $^{1 \#}$, ANNAMARIA PALLAG $^{2 \#}$, MARIANN KOZMA $^{1}$, CSABA HEGEDUS $^{3}$, \\ DIANA KOVACS ${ }^{1}$, HAJNALKA GULYAS ${ }^{1}$, MIHAELA ZDRINCA ${ }^{4}$, IOAN MAGYAR ${ }^{4}$, \\ FELICIA MARC $^{4}$, SEBASTIAN NEMETH ${ }^{2 *}$, RITA KISS ${ }^{1}$ \\ ${ }^{I}$ Department of Pharmacology and Pharmacotherapy, Faculty of Medicine, University of Debrecen, 98 Nagyerdei krt., $H$ - \\ 4032 Debrecen, Hungary \\ ${ }^{2}$ Department of Pharmacy, Faculty of Medicine and Pharmacy, University of Oradea, 29 Nicolae Jiga Street, R-410028 \\ Oradea, Romania \\ ${ }^{3}$ Cera-Med Ltd, 1 Kútvölgyi u, H-4225 Debrecen, Hungary \\ ${ }^{4}$ Preclinical Disciplines Department, Faculty of Medicine and Pharmacy, University of Oradea, 101 Decembrie Square, $R$ - \\ 410073 Oradea, Romania \\ ${ }^{5}$ Medical Disciplines Department, Faculty of Medicine and Pharmacy, University of Oradea, 101 Decembrie Square, R- \\ 410073 Oradea, Romania
}

*corresponding author: sebinemeth@yahoo.com

${ }^{*}$ Authors with equal contribution

\begin{abstract}
In the present study we investigated the effects of chronic oral treatment with fenugreek seeds (Trigonella foenum-graecum, TFG) and diosgenin (DG), one of its saponins, on diet induced obese (DIO) rats. Under the six weeks long treatment period metabolic parameters such as body weight, food and water intake were daily measured. At the end of the 6 weeks we performed insulin tolerance test (ITT). After 6 weeks of high fat diet the animals developed obesity. TFG treatment worsened the effects of diet induced obesity on body weight, abdominal adiposity and energy intake, but it had no effect on insulin sensitivity. Diosgenin alone did not show significant effects on the examined parameters. We conclude that diosgenin alone did not cause any particular body weight or fat gain, but is likely to interact in a complex manner with the other ingredients of the fenugreek seeds.
\end{abstract}

\section{Rezumat}

În prezentul studiu am investigat efectele semințelor de schinduf (Trigonella foenum-graecum (TFG)) și a uneia dintre saponinele sale, diosgenina, asupra modelului de obezitate indusă prin dietă. Pe parcursul tratamentului de şase săptămâni zilnic au fost măsurate parametrii metabolici, ca de exemplu greutatea corporală, și consumul de hrană și apă. La sfârșitul perioadei de tratament - în săptămâna a 6-a am determinat sensibilitatea la insulină cu testul de toleranţă la insulină (ITT). După 6 săptămâni de dietă hipercalorică animalele au dezvoltat obezitate. Tratamentul cu semințe de schinduf a agravat efectele obezității induse de dietă asupra greutății corporale, a adipozității abdominale și a consumului de energie, dar nu a avut niciun efect asupra sensibilității la insulină. Diosgenina în monoterapie nu a prezentat efecte semnificative asupra parametrilor examinați. Am concluzionat că diosgenina în monoterapie nu a produs nici o creștere particulară în greutatea corporală sau a adipozității abdominale, dar este probabil să interacționeze într-o manieră complexă cu alte ingrediente ale semințelor de schinduf.

Keywords: fenugreek, diosgenin, obesity, insulin resistance

\section{Introduction}

Obesity has reached epidemic proportions on a global level in the past few decades. Obesity is associated with an increased risk of developing insulin resistance and type 2 diabetes (T2DM), hypertension, atherosclerosis and certain tumours $[6,16,27]$. The lifestyle of western culture, which consists of an unhealthy diet and insufficient physical exercise, highly contributes to the development of obesity and related diseases. Despite the amount of scientific attention towards obesity, proper pharmacological therapy is still not available. However, there is a growing interest towards the possible therapeutic applications of natural bioactive compounds.

Since ancient times, plants represent an excellent source of biologically active substances, and a large proportion of currently-available drugs are either derived directly or indirectly from plant sources [8, 22-24]. Literature suggests that there are more than 800 plants that may possess hypoglycaemic activity [10], this means that 
there might be a potential alternative in the treatment of T2DM. Although numerous medicinal plants are being used in supportive treatment of T2DM, a significant amount of research suggests that fenugreek seeds are among the best in terms of safety and efficacy [10, 14, 21, 24, 28, 34], containing numerous biologically active compounds, providing high medicinal and nutritional profile: fibre, phospholipids, glycolipids, oleic acid, linoleic acid, steroid sapogenins, 4-OH isoleucine, galactomannan and many other functional elements such as vitamins A, B1, B2, C, choline, nicotinic acid, niacin and minerals $[1,2,10$, 19]. The Trigonella foenum-graecum is also listed in the Pharmacopoeia. The Fenugreek seeds have also been shown to exert significant antiatherogenic, antidiabetic, antianorexic, antihyperlipidaemic, antioxidant, antiinflammatory and gastro-protective effects is several human and animal models [1, 24, 28, 32, 34-36]. Moreover, treatments with fenugreek seeds have multiple benefits in patients with diabetes mellitus [3]. Research in the past two decades has shown that fenugreek seeds have positive effect on blood glucose level and glucose tolerance in patients with diabetes mellitus [21]. Fenugreek has been shown to exert a significant impact on the metabolism of lipids and glucose, it is also insulin-sensitizing, has antioxidant effects, and it contributes to keeping the energy balance [3].

In the present study we investigated the effects of chronic oral treatment with fenugreek seeds and diosgenin, one of its saponins, on diet induced obese rats. Under the six week long treatment period we measured the body weight, food and water consumption on a daily basis. At the end point of the experimental protocol, on the sixth week, we measured the insulin sensitivity using insulin tolerance test.

\section{Materials and Methods}

The study was in concordance with the Declaration of Ethics in Decommissioning 08/2007 DE MÁB and $16 / 2007$ DE MÁB, and the study complied with the international (EU and US) Recommendation on the Treatment of Experimental Animals (published in 1996 at the National Academy Press, 2101 Constitution Ave. NW, Washington DC 20055, USA).

For the study we used a diet induced obesity rat model. The male Wistar rats $(n=60)$ were housed in an animal room with $22-24^{\circ} \mathrm{C}$ and $50-70 \%$ relative humidity. The lighting was set to $12 \mathrm{~h}$ light and $12 \mathrm{~h}$ dark period. After a week of acclimatization period, rats were equally and randomly assigned into six groups. Three animals per each group were individually placed into metabolic cages (3701M081, Tecniplast, Italy), the rest was kept in standard rat cages, 3 - 4 animal per cage. Rats in the control group were fed $a d$ libitum with standard laboratory chow (S8106-S011 SM R/M-Z+H, ssniff Spezialdiäten GmbH, Germany) and tap water, and the other five groups were DIO animals. Obesity was induced with a special rodent chow rich in fat (high fat diet, HFD) (RM AFE $45 \%$ FAT $20 \%$ CP $35 \%$ CHO (P), Special Diets Services, UK) and 5\% sucrose solution. DG in different concentrations $(1,10$ and $50 \mathrm{mg} / \mathrm{kg})$ or TFG seeds $(0.6 \mathrm{~g} / \mathrm{kg})$ were mixed into the chow of the treated DIO rats (Table I). The experiment lasted for 6 weeks.

Table I

Composition of prepared foodstuffs per $\mathrm{kg}$ of weight

\begin{tabular}{|l|c|c|c|c|c|}
\hline \multicolumn{1}{|c|}{ Groups } & \multicolumn{5}{|c|}{ Diet } \\
\hline \multicolumn{1}{|c|}{ Control group } & \multicolumn{5}{|c|}{ Standard chow } \\
\hline & DG/TFG $(\mathrm{mg})$ & High fat diet chow $(\mathrm{g})$ & Sesame oil $(\mathrm{mL})$ & Gelatine $(\mathrm{g})$ & Water $(\mathrm{mL})$ \\
\hline HFD control group & 0 & 854.7 & 14.25 & 6.55 & 124.5 \\
\hline HFD 1 mg/kg DG & 15.7 & 854.7 & 14.25 & 6.55 & 124.5 \\
\hline HFD 10 mg/kg DG & 156.7 & 854.7 & 14.25 & 6.55 & 124.5 \\
\hline HFD 50 mg/kg DG & 783.5 & 854.7 & 14.25 & 6.55 & 124.5 \\
\hline HFD 0.6 g/kg TFG seed & 18201.9 & 827.36 & 13.79 & 7.03 & 133.62 \\
\hline
\end{tabular}

\section{Metabolic measurements}

For the animals kept in metabolic cages body weight, food- and water consumption, urine and stool production were measured every morning, except at weekends when a 3-days average was calculated on the next Monday morning. The body weights of the animals being kept in normal cages were measured twice a week, the food- and water consumption were determined on a daily basis. The amount of DG or TFG being mixed in the chow was calculated from the body weight and daily food consumption data every week.
The daily calorie intake was calculated according to the following formula: standard chow: $3.2 \mathrm{kcal} / \mathrm{g}$, HFD: $4.56 \mathrm{kcal} / \mathrm{g}, 5 \%$ sucrose solution: $0.2 \mathrm{kcal} / \mathrm{mL}$. At the end of the treatment period the abdominal white adipose tissue (retroperitoneal, gonadal) was removed and measured.

\section{Determination of insulin sensitivity}

Insulin tolerance test (ITT) was carried out on week 6 . Before the experiment, the animals were fasted for 3 hours, and then, the basal blood glucose levels were determined via a tail clip. Blood glucose concentration was determined by means of glucometer (Accu-Chek, Roche Diagnostics, Budaörs, Hungary). After basal 
blood glucose measurements, $0.5 \mathrm{U} / \mathrm{kg}$ insulin was administered intraperitoneally, then blood glucose was measured at 30, 60, 90 and $120 \mathrm{~min}$. Insulin tolerance was estimated from area under the glucose curve.

Statistics

All data were analysed with one-way analysis of variance (ANOVA) followed by a modified t-test for repeated measures according to Bonferroni's method was used. Data were presented as mean \pm SEM. *, ** and $* * *$ indicated significant difference compared to the control group $(\mathrm{p}<0.05, \mathrm{p}<0.01$ and $\mathrm{p}<0.001$, respectively). \#, \#\# and \#\#\# indicated significant difference compared to the HFD control group ( $\mathrm{p}<$ $0.05, \mathrm{p}<0.01$ and $\mathrm{p}<0.001$, respectively).

\section{Results and Discussion}

Metabolic measurements

Figure 1 shows the effects of diosgenin and fenugreek seed treatment on body weight. The animals treated with $1 \mathrm{mg} / \mathrm{kg}$ diosgenin and $0.6 \mathrm{~g} / \mathrm{kg}$ fenugreek seeds showed a significant increase from day 4 compared to healthy controls, and that significant difference was maintained throughout the experimental period.

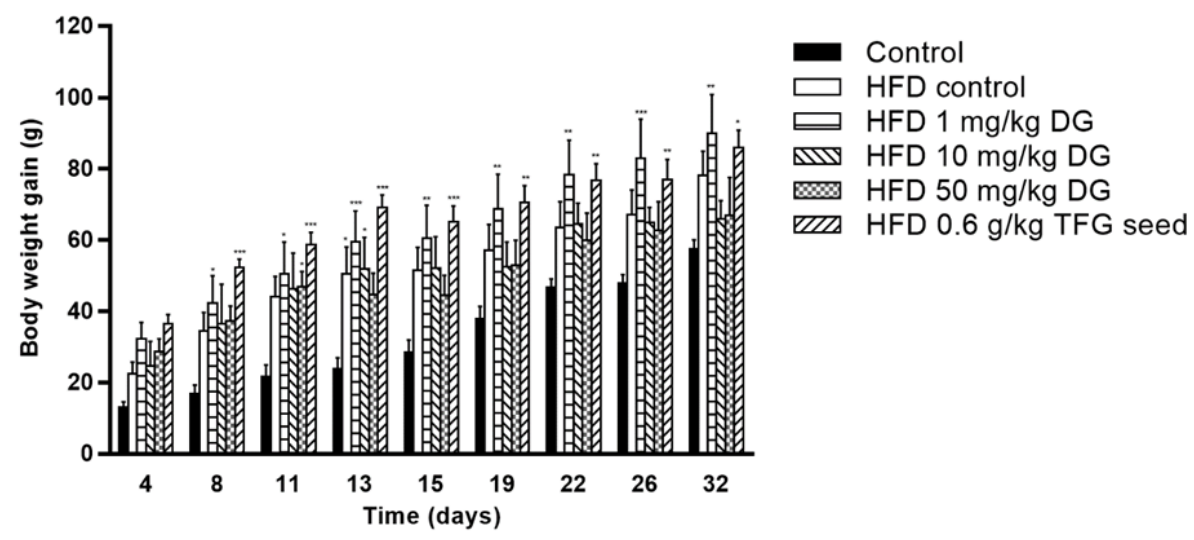

Figure 1.

Effect of chronic diosgenin and fenugreek seed treatment on body weight gain

The *, ${ }^{*}$ and $* * *$ indicates significant difference compared to the control group $(\mathrm{p}<0.05, \mathrm{p}<0.01$ and $\mathrm{p}<0.001$, respectively)

The TFG is not a weight loss promoting agent, it is frequently used as a nutritional supplement in the treatment of diabetes mellitus, because of its blood glucose normalizing and insulin sensitizing effect, our research, however, demonstrated that the western diet combined with a small dosage of TFG increases the risk of weight gain or obesity. This novel observation can be considered as an important side effect of TFG, and it is our suggestion that patients who use TFG as food supplement, or physicians who prescribe it should take care of proper dosing to avoid the possible undesired effect of TFG on body weight.

Diet rich in fat and sugar resulted in a significant difference in white adipose tissue (WAT) accumulation, however, there was no visible dose-response correlation between the different doses of diosgenin regarding adipose tissue weight, not even with the HFD 10 $\mathrm{mg} / \mathrm{kg}$ DG group which showed the largest weight gain compared to healthy controls. Fenugreek on the other hand caused a significant increase compared to the control group, as seen in Figure 2.

Although the effects are significant compared to the control but not to the HFD control group, we observed that in high dosage, diosgenin and TFG manifest a tendency to decrease the amount of WAT (Figure 2).

On the contrary, low dosages of diosgenin and TFG seed are not able to counterbalance the effects of HFD. TFG seeds, besides causing obesity, also increase the abdominal WAT, which is in correlation with the appearance of diabetes mellitus.
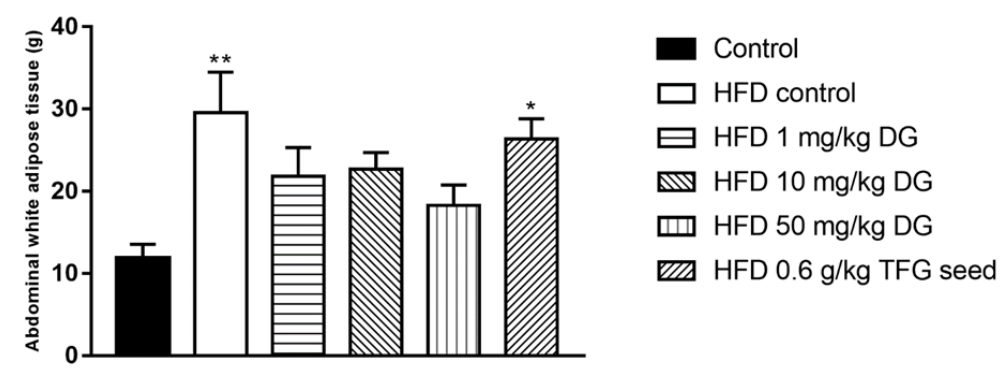

Figure 2.

Effect of chronic diosgenin and fenugreek seed treatment on the weight of abdominal white adipose tissue The * and ** indicates significant difference compared to the control group ( $\mathrm{p}<0.05$ and $\mathrm{p}<0.01$, respectively) 
Figure 3 and Figure 4 show the food and water consumption during the treatment period. We found that all HFD groups consumed significantly less food compared to the control group. At the same time water consumption increased significantly in the 10 $\mathrm{mg} / \mathrm{kg}$ and $50 \mathrm{mg} / \mathrm{kg}$ diosgenin and fenugreek groups.
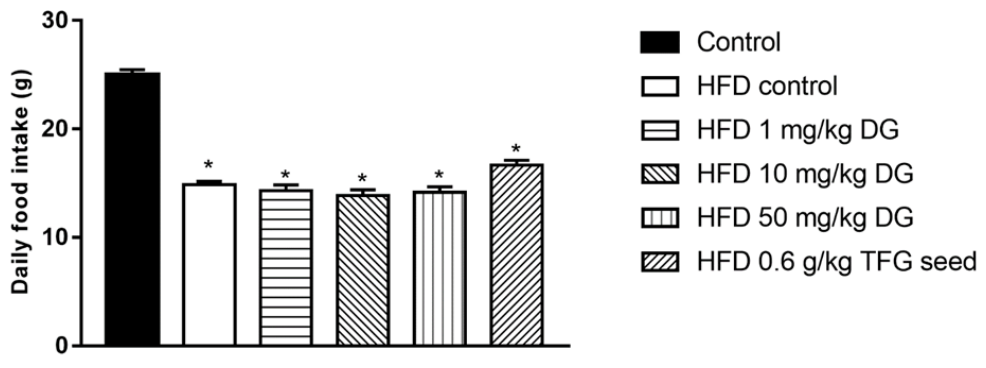

Figure 3.

Effect of chronic diosgenin and fenugreek seed treatment on daily food intake The * indicates significant difference compared to the control group $(\mathrm{p}<0.05)$
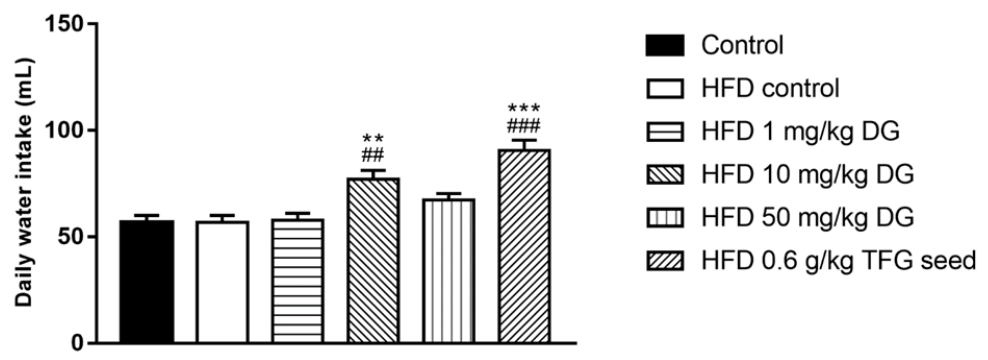

Figure 4.

Effect of chronic diosgenin and fenugreek seed treatment on daily water intake

The ** and $* * *$ indicates significant difference compared to the control group $(\mathrm{p}<0.01$ and $\mathrm{p}<0.001$, respectively)

The \#\# and \#\#\# indicates significant difference compared to the HFD control group ( $p<0.01$ and $p<0.001$, respectively)

The daily calorie intake was determined as written above. High-fat diet contains more calories than normal chow, however, sucrose solution adds additional calories to the daily energy intake in the HFD groups. We found that the HFD control and the diosgenin treated group took the same amount of calories per day compared to the control group. However, the energy intake of the fenugreek treated rats was significantly increased compared to the HFD control and diosgenin treated groups, as shown in Figure 5.

The rats ate less during the experimental period (Figure 3 ), but their calorie intake has increased due to the high fat diet containing a great amount of energy as shown in Figure 5. This can explain why the TFG increases not only the abdominal WAT, but the body weight as well.

In addition, the animal cages were not supplied with running wheel or other means that could have allowed the rats to burn the excessive calories ingested, therefore they could not compensate for the increased energy intake, and consequently, the balance between energy consumption and energy expenditure is turned towards weight gain.

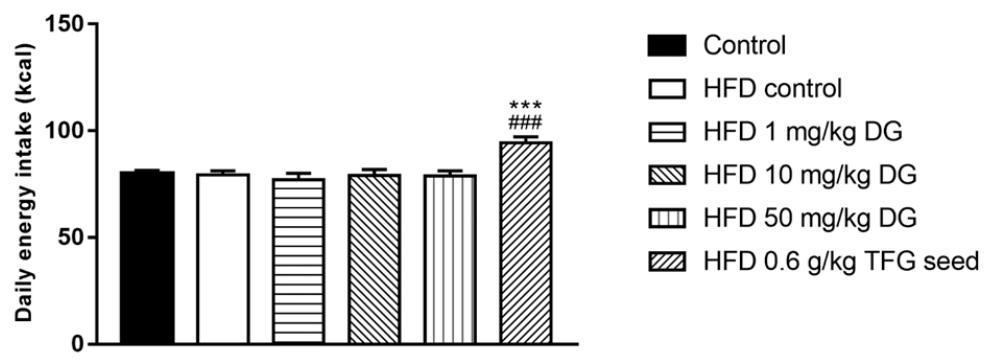

Figure 5.

Effect of chronic diosgenin and fenugreek seed treatment on daily energy intake

The $* * *$ indicates significant difference compared to the control group $(\mathrm{p}<0.001)$

The \#\#\# indicates significant difference compared to the HFD control group $(p<0.001)$.

Our results show that while the diet induced obese rats reduced food intake to compensate for the energy rich diet, they gained body weight at a larger rate, and in HFD controls the weight of abdominal white 
FARMACIA, 2019, Vol. 67, 1

adipose tissue was significantly elevated. Diosgenin treatment alone was unable to balance the negative effects of high fat diet on body weight, adiposity and energy metabolism. In turn, our data pointed out that chronic treatment with fenugreek seed worsened the aforementioned parameters, which suggests that it is not diosgenin, but other bioactive compounds present in TFG that are responsible for the metabolic alterations. Recent research result highlighted the role of 4-OH isoleucine or galactomannan in the glucose tolerance improving and insulin sensitizing effect of

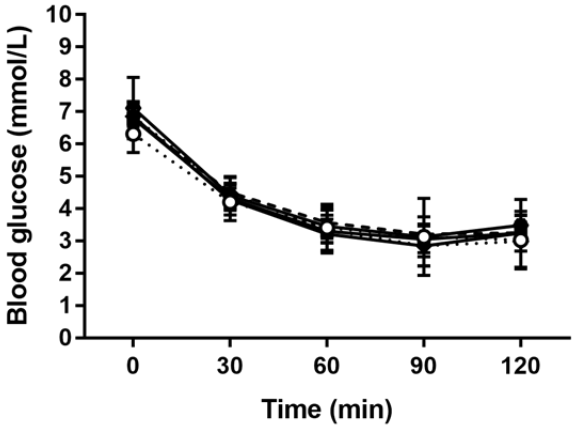

Figure 6.

Effect of chronic diosgenin and fenugreek seed treatment on blood glucose levels during ITT
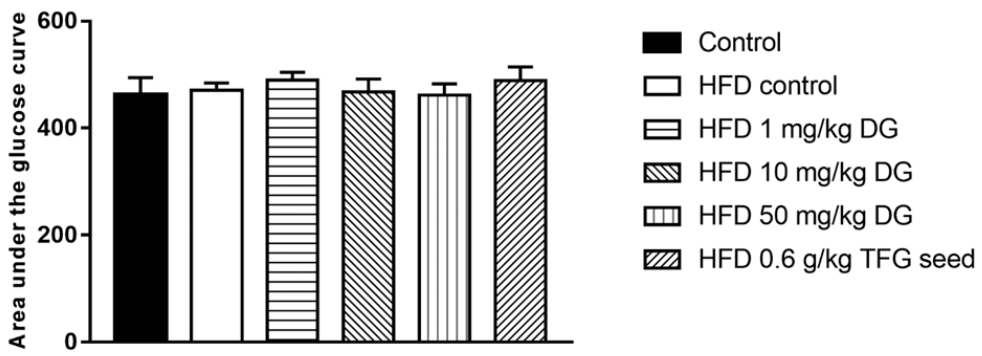

Figure 7.

Effect of chronic diosgenin and fenugreek seed treatment on area under the glucose curve during ITT

Our data showed that despite TFG enhanced weight gain and increased abdominal adiposity, parameters well connected to the development of insulin resistance, 6 weeks treatment with fenugreek seeds didn't alter insulin sensitivity. It is well established that fenugreek has an insulin sensitizing effect $[4,5,15,25,30,31]$ and delays the development of glucose intolerance in sensitive patients, but our results with diosgenin could not corroborate this, which suggests that sapogenins do not play a significant role in the insulin sensitizing effect of TFG, and the applied dose of TFG is not enough to increase insulin sensitivity in the DIO model.

\section{Conclusions}

Chronic treatment with fenugreek increased the body weight gain caused by fat and sugar rich diet. Abdominal adiposity and consumed calories in the TFG group was also increased compared to control and DIO control animals. But despite its negative fenugreek seeds $[5,12,20,30]$. The effect of fenugreek in body weight gain might be related to the wellestablished fact that TFG is able to act on hormones in the central nervous system involved in the regulation food intake such as melanin concentrating hormone $(\mathrm{MCH})$. Fenugreek is able to act as an $\mathrm{MCH}$ agonist $[7,9,11,13,17,18,25,29,33]$.

Insulin sensitivity

During the insulin tolerance test there was no difference regarding the area under the curve between groups (Figure 6, Figure 7).

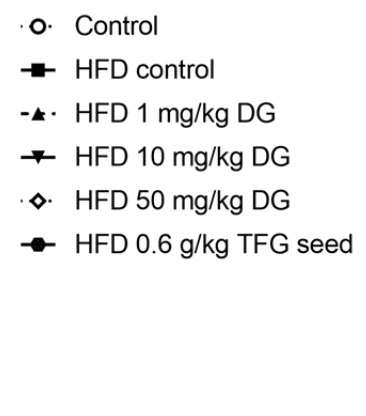


FARMACIA, 2019, Vol. 67, 1

Further investigations will be carry out, with other doses of TFG, and also there will be performed other methods in the determination of insulin sensitivity, such as glucose tolerance test and hyperinsulinaemia euglycaemic glucose clamp.

\section{Acknowledgement}

This study was supported by the Hungarian-European Research Infrastructure Network (EFOP-3.6.2-162017-00009).

\section{References}

1. Ahmad A, Alghamdi SS, Mahmood K, Afzal M, Fenugreek a multipurpose crop: Potentialities and improvements. Saudi J Biol Sci., 2016; 23: 300-310.

2. Altuntas E, Özgöz E, Taser O, Some physical properties of fenugreek (Trigonella foenum-graecum L.) seeds. J Food Engineering, 2005; 71: 37-43.

3. Ansari R, Ansari S, Effectiveness of fenugreek for lowering hemoglobin $(\mathrm{HbAlc})$ in patients with selfmanagement of type 2 diabetes: A randomized controlled trial. Medical Complications of Type 2 Diabetes, IntechOpen, 2011; 392-412.

4. Arshadi S, Ali Azarbayjani M, Hajiaghaalipour F, Yusof A, Peeri M, Bakhtiyari S, Stannard RS, Abu Osman NA, Dehghan F, Evaluation of Trigonella foenum-graecum extract in combination with swimming exercise compared to glibenclamide consumption on type 2 Diabetic rodents. Food Nutr Res., 2015; 59: 29717: 1-9.

5. Avalos-Soriano A, de la Cruz-Cordero R, Rosado LJ, Garcia-Gasca T, 4-Hydroxyisoleucine from fenugreek (Trigonella foenum-graecum): Effects on insulin resistance associated with obesity. Molecules, 2016; 21(11): 1596: 1-12.

6. Bhupathiraju SN, Hu FB, Epidemiology of obesity and diabetes and their cardiovascular complications. Circ Res., 2016; 118: 1723-1735.

7. Chen Y, Hu C Hsu CK, Zhang Q, Bi C, Asnicar M, Hsiung HM, Fox N, Slieker LJ, Yang DD, Heiman ML, Shi Y, Shi Y, Targeted disruption of the melaninconcentrating hormone receptor-1 results in hyperphagia and resistance to diet-induced obesity. Endocrinology, 2002; 143(7): 2469-2477.

8. Copolovici D, Bungau S, Boscencu R, Tit DM, Copolovici L, The fatty acids composition and antioxidant activity of walnut cold press oil. Rev Chim (Bucharest), 2017; 68(3): 507-509.

9. Della-Zuana O, Presse F, Ortola C, Duhault J, Nahon JL, Levens N, Acute and chronic administration of melanin-concentrating hormone enhances food intake and body weight in Wistar and Sprague-Dawley rats. Int J Relat Metab Disord., 2002; 26(10): 1289-1295.

10. Eidi A, Eidi M, Sokhteh M, Effect of fenugreek (Trigonella foenum-graecum L) seeds on serum parameters in normal and streptozotocin-induced diabetic rats. Nutrition Res., 2007; 27(11): 665-734.

11. Gomori A, Ishihara A, Ito M, Mashiko S, Matsushita H, Yumoto M, Ito M, Tanaka T, Tokita S, Moriya M, Iwaasa H, Kanatani A, Chronic intracerebroventricular infusion of $\mathrm{MCH}$ causes obesity in mice. $\mathrm{Am} J$ Physiol Endocrin Metab., 2003; 284: 583-588.
12. Hamden K, Jaouadi B, Carreau S, Bejar S, Elfeki A, Inhibitory effect of fenugreek galactomannan on digestive enzymes related to diabetes, hyperlipidemia, and liver-kidney dysfunctions. Biotech Bioproc Engin., 2010; 15: 407-413.

13. Isaia IA, Toth C, Osser G, Pallag A, Sirbu V, Honiges A, Comparative analysis upon action of aqueous and alcoholic Trigonella sp. extracts on fibroblasts culture. Rev Chim (Bucharest), 2017; 68(3): 562-565.

14. Jurca T, Baldea I, Filip GA, Olteanu D, Clichici S, Pallag A, Vicas L, Marian E, Micle O, Muresan M, The effect of Tropaeolum Majus L. on bacterial infections and in vitro efficacy on apoptosis and dna lesions in hyperosmotic stress. $J$ Physiol Pharmac., 2018; 69(3): 391-401.

15. Kiss R, Szabó K, Gesztelyi R, Somodi S, Kovács P, Szabó Z, Németh J, Priksz D, Kurucz A, Juhász B, Szilvássy Z, Insulin-Sensitizer Effects of Fenugreek Seeds in Parallel with Changes in Plasma MCH Levels in Healthy Volunteers. Int J Mol Sci., 2018; 19(3): 771-776.

16. Legler J, Fletcher T, Govarts E, Porta M, Blumberg B, Heindel JJ, Trasande L, Obesity, Diabetes, and Associated Costs of Exposure to Endocrine-Disrupting Chemicals in the European Union. J Clin Endocrin Metab., 2015; 100: 1278-1288.

17. Lupascu FG, Avram I, Confederat L, Constantin SM, Stan CI, Lupascu EC, Sava A, Profire L, Biological evaluation of chitosan-antidiabetic drug formulations for the treatment of diabetes mellitus. Farmacia, 2017; 65(4): 508-514.

18. Marsh DJ, Weingarth D, Novi DE, Chen HY, Chen AS, Guan XM, Jiang MM, Feng Y, Camacho RE, Shen Z, Frazier EG, Yu H, Metzger JM, Kuca SJ, Shearman LP, Gopal-Truter S, MacNeil DJ, Strack AM, MacIntyre DE, Van der Ploeg LHT, Qian S, Melanin-concentrating hormone 1 receptor-deficient mice are lean, hyperactive, and hyperphagic and have altered metabolism. Proc Natl Acad Sci USA, 2002; 99(5): 3240-3245.

19. Mraz C, Mureșan M, Micle O, Vicaș L, Pallag A, Coltău M, Pușcaș I, Effect of vitamin D on carbonic anhydrase activity experimental reasearch in vitro and in vivo. Farmacia, 2012; 60(2): 264-271.

20. Narender T, Puri A, Shweta, Khaliq T, Saxena R, Bhatia G, Chandra R, 4-Hydroxyisoleucine an unusual amino acid as antidyslipidemic and antihyperglycemic agent. Bioorg Med Chem Lett., 2006; 16: 293-296.

21. Neelakantan N, Narayanan M, de Souza R, van Dam $\mathrm{R}$, Effect of fenugreek (Trigonella foenum-graecum $\mathrm{L}$.) intake on glycemia: A meta-analysis of clinical trials. Nutrition J., 2014; 13(7): 1-11.

22. Pallag A, Paşca B, Jurca T, Suciu R, Nemeth S, Vicaş $\mathrm{L}$, Comparative histo-anatomical researches on the vegetative organs and assessment of antioxidant capacity of two species from Equisetum Genus. Farmacia, 2016; 64(3): 372-377.

23. Pandey A, Tripathi P, Pandey R, Srivatava R, Goswami $S$, Alternative therapies useful in the management of diabetes: A systematic review. J Pharm Bioall Sci., 2011; 3: 504-512.

24. Patel DK, Kumar R, Laloo D, Hemalatha S, Diabetes mellitus: An overview on its pharmacological aspects 
and reported medicinal plants having antidiabetic activity. As Pac J Trop Biomed., 2012; 2: 411-420.

25. Qu D, Ludwig DS, Gammeltoft S, Piper M, Cullen MJ, Mathes WF, Przypek R, Kanarek R, MaratosFlier $\mathrm{E}$, A role for melanin-concentrating hormone in the central regulation of feeding behaviour. Nature, 1996; 380(6571): 243-247.

26. Rosa FT, Zulet MÁ, Marchini JS, Martínez JA, Bioactive compounds with effects on inflammation markers in humans. Int J Food Sci Nutr., 2012; 63: 749-765.

27. Scherer PE, Hill JA, Obesity, diabetes, and cardiovascular diseases: A compendium. Circ Res., 2016; 118: 1703-1705.

28. Sindhu G, Ratheesh M, Shyni GL, Nambisan B, Helen A, Anti-inflammatory and antioxidative effects of mucilage of Trigonella foenum graecum (Fenugreek) on adjuvant induced arthritic rats. Int Immunopharmacol., 2012; 12: 205-211.

29. Siriwardhana N, Kalupahana NS, Cekanova M, LeMieux M, Greer B, Moustaid-Moussa N, Modulation of adipose tissue inflammation by bioactive food compounds. J Nutr Biochem., 2013; 24: 613-623.

30. Srichamroen A, Field CJ, Thomson ABR, Basu TK, The modifying effects of galactomannan from Canadiangrown fenugreek (Trigonella foenum-graecum L.) on the glycemic and lipidemic status in rats. $J$ Clin Biochem Nutr., 2008; 43: 167-174.
31. Sriramajayam K, Venkataraman A, Insulin sensitizing actions of fenugreek seed polyphenols, quercetin \& metformin in a rat model. Ind $J$ Med Res., 2009; 129: 401-408.

32. Suja Pandian R, Anuradha CV, Viswanathan P, Gastroprotective effect of fenugreek seeds (Trigonella foenum graecum) on experimental gastric ulcer in rats. J Ethnopharmacol., 2002; 81: 393-397.

33. Szilvássy Z, Tóth P, Földi E, Lampé Z, Mészáros J, Anton $P$, Natural feed mixture for breeding domesticated water birds. EP 27457003A1, 2014.

34. Tharaheswari M, Jayachandra Reddy N, Kumar R, Varshney KC, Kannan M, Sudha Rani S, Trigonelline and diosgenin attenuate ER stress, oxidative stressmediated damage in pancreas and enhance adipose tissue PPAR gamma activity in type 2 diabetic rats. Mol Cell Biochem., 2014; 396(1-2): 161-174.

35. Velescu BS, Anuţa V, Aldea A, Jinga M, Cobeleschi PC, Zbârcea CE, Uivaroși V, Evaluation of protective effects of quercetin and vanadyl sulphate in alloxan induced diabetes model. Farmacia, 2017; 65(2): 200-206

36. Zhou J, Chan L, Zhou S, Trigonelline: A Plant Alkaloid with Therapeutic Potential for Diabetes and Central Nervous System Disease. Curr Med Chem., 2012; 19: 3523-3531. 